\title{
Nitrate: ammonium nutrition alleviates detrimental effects of salinity by enhancing photosystem II efficiency in sorghum plants ${ }^{1}$
}

\author{
Rafael de S. Miranda ${ }^{2}$, Rosilene O. Mesquita ${ }^{3}$, Natanael S. Freitas ${ }^{4}$, José T. Prisco ${ }^{5}$ E Enéas Gomes-Filho ${ }^{6}$ \\ ${ }^{1}$ Trabalho selecionado do II INOVAGRI International Meeting, realizado de 13 a 16 de abril de 2014, Fortaleza - CE, Brasil \\ ${ }^{2}$ Pós-Graduação em Bioquímica/UFC. Fortaleza, CE. E-mail: rafaelmyranda@hotmail.com \\ ${ }^{3}$ DCR/FUNCAP/CNPq/UFC. Fortaleza, CE. E-mail: rosilenemesquista@gmail.com \\ ${ }^{4}$ Curso de Ciências Biológicas/UFC. Fortaleza, CE. E-mail: natanfreitas20@gmail.com \\ ${ }^{5}$ Professor/Pesquisador/INCTSal/CNPq/UFC. Fortaleza, CE. E-mail: jtprisco@uol.com.br \\ ${ }^{6}$ INCTSal/CNPq/UFC. Fortaleza, CE. E-mail: egomesf@ufc.br (Autor correspondente)
}

Key words:

salt stress

Sorghum bicolor

nitrogen nutrition

\begin{abstract}
A B S T R A C T
This study was carried out to evaluate if replacement of nitrate $\left(\mathrm{NO}_{3}^{-}\right)$by ammonium $\left(\mathrm{NH}_{4}^{+}\right)$in the growth medium prevents the damage in the photosystem II (PSII) efficiency and degradation of photosynthetic pigments caused by saline stress in sorghum plants. Sorghum bicolor plants were cultivated in nutrient solutions containing different $\mathrm{NO}_{3}: \mathrm{NH}_{4}{ }^{+}$ratios $(100: 0,75: 25,50: 50,25: 75$ and $0: 100)$ at a final concentration of $5.0 \mathrm{mM}$. Salinity was imposed by adding $\mathrm{NaCl}$ at $75 \mathrm{mM}$ in the growth medium; and the analysis were performed after ten days of salt stress. The most striking effects of nitrogen regime were observed in plants supplied with equal amounts of $\mathrm{NO}_{3}^{-}: \mathrm{NH}_{4}^{+}$ (50:50). Under salt stress, 50:50-grown plants displayed an increase in the photosystem II maximum efficiency (Fv/ Fm), which was associated with a lower non-photochemical quenching (NPQ). The superior performance of saltstressed plants grown in 50:50 ratio was indicated by a higher effective quantum yield of PSII (ФPSII) and electron transport rate (ETR), as well as increased chlorophyll b and anthocyanins. In conclusion, nitrogen nutrition with same amounts of nitrate and ammonium avoids the degradation of photosynthetic pigments and allows higher PSII efficiency in salt-stressed sorghum plants.

\section{Nutrição com nitrato e amônio minimiza os efeitos prejudiciais da salinidade pelo aumento da eficiência do fotossistema II em plantas de sorgo}

Palavras-chave: estresse salino Sorghum bicolor nutrição de nitrogênio

\begin{abstract}
R E S U M O
O objetivo deste estudo foi verificar se a substituição de nitrato $\left(\mathrm{NO}_{3}^{-}\right)$por amônio $\left(\mathrm{NH}_{4}^{+}\right)$, no meio de crescimento, previne os danos na eficiência do fotossistema II (PSII) e a degradação de pigmentos fotossintéticos causados pela salinidade em plantas de sorgo. As plantas foram cultivadas em soluções nutritivas com diferentes relações dos íons $\mathrm{NO}_{3}^{-} \mathrm{e} \mathrm{NH}_{4}^{+}(100: 0,75: 25,50: 50,25: 75$ e 0:100) a 5,0 mM. O estresse salino foi imposto pela adição de $75 \mathrm{mM}$ de $\mathrm{NaCl}$ no meio de crescimento e as análises foram realizadas após dez dias de estresse. Os efeitos mais marcantes da nutrição com nitrogênio foram observados em plantas nutridas na relação 50:50. Sob condições de estresse salino, plantas nutridas nessa relação apresentaram aumentos na eficiência máxima do fotossistema II (Fv/Fm), os quais foram associados com menores coeficientes de extinção não-fotoquímica (NPQ). Adicionalmente, plantas estressadas nutridas na relação 50:50 apresentaram maior rendimento quântico efetivo do PSII (ФPSII) e altas taxas de transporte de elétrons (ETR), bem como aumentos nos teores de clorofila b e de antocianinas. A análise em conjunto dos resultados sugere que a nutrição nitrogenada com quantidades iguais dos íons nitrato e amônio previne a degradação de pigmentos fotossintéticos e permite maior eficiência do PSII em plantas de sorgo sob estresse salino.
\end{abstract}

\section{INTRODUCTION}

Salinity is one of the most severe factors limiting plant growth and yield. Photosynthesis is a physiological process closely related to crop productivity. Decline of photosynthetic capacity commonly occurs in salt stressed plants, but the underlying mechanisms are complex and remain unclear (Saleem et al., 2011). Photosystem II (PSII) plays an important role in plant photosynthesis, and it often operates abnormally under environmental stress (Havaux, 1992; Baker, 2008).

Over-reduction because of electron excess on thylakoid membranes is frequently related under salinity (Szepesi et al., 2005; Aragão et al., 2012). In order to avoid or minimize photo-damage, photo-inhibition and oxidative stress, the plants can deploy several mechanisms such as photorespiration, heat dissipation and the xanthophyll cycle. Recently, evidence 
has emerged that $\mathrm{N}$ metabolism and respiration may also be involved in energy dissipation (Osmond \& Foster, 2006; Aragão et al., 2012).

Nitrogen availability has been cited as important strategy to induce salt stress acclimation in plants (Kant et al., 2007; Fernández-Crespo et al., 2012; Miranda et al., 2013a). Nitrogen is required in large quantities by plants and is taken up in the form of ammonium $\left(\mathrm{NH}_{4}^{+}\right)$and nitrate $\left(\mathrm{NO}_{3}^{-}\right)$. High supply of $\mathrm{NO}_{3}{ }^{-}$mitigated the salinity effects through an enhancement in the efficiency of photosystem II and $\mathrm{CO}_{2}$ assimilation in Jatropha curcas plants (Aragão et al., 2012). On the other hand, although $\mathrm{NH}_{4}^{+}$assimilation is energetically more favorable than $\mathrm{NO}_{3}^{-}$, it is usually toxic for some plant species (Britto \& Kronzucker, 2002). However, a combined nutrition by using $\mathrm{NO}_{3}^{-}$and $\mathrm{NH}_{4}^{+}$induced a substantial reduction in the harmful effects of salinity compared with $\mathrm{NO}_{3}^{-}$supply (Kant et al., 2007; Zhonghua et al., 2011).

This study aimed to investigate whether replacement of $\mathrm{NO}_{3}^{-}$by $\mathrm{NH}_{4}^{+}$in the growth medium prevents the damage in the photosystem II efficiency and degradation of photosynthetic pigments caused by saline stress in Sorghum bicolor plants. Therefore, the differences in PSII photochemistry between plants grown in several $\mathrm{NO}_{3}^{-}: \mathrm{NH}_{4}^{+}$ratios in response to salt stress was investigated, as well as the role of nitrogen nutrition in mitigating the possible damage in the photosynthetic pigments as affected by salinity was also analyzed.

\section{Materials ANd Methods}

Seeds of forage sorghum [Sorghum bicolor (L.) Moench] of the genotype CSF20, provided by Instituto Agronômico de Pernambuco (IPA), Brazil, were sterilized with $2 \%$ sodium hypochlorite for $5 \mathrm{~min}$ and then washed with distilled water. Thereafter, the seeds were sown in vermiculite moistened with distilled water. Four days after sowing (DAS), the seedlings were transferred to a tray containing Hoagland's nutrient solutions formulated to contain inorganic nitrogen at $5.0 \mathrm{mM}$, supplied as $\mathrm{NO}_{3}{ }^{-}$and/or $\mathrm{NH}_{4}{ }^{+}$. The nitrogen treatments were as follows: percentage of $\mathrm{NO}_{3}{ }^{-}$in relation to $\mathrm{NH}_{4}{ }^{+}$of 100:0, 75:25, 50:50, 25:75 and 0:100. Twelve DAS, the plants were subjected to salt stress with $\mathrm{NaCl}$ at 0 (control) and $75 \mathrm{mM}$, which was applied in doses of $37.5 \mathrm{mM}$ per day to avoid osmotic shock.

Nutrient solutions were renewed every three days and the plants were harvested ten days after the last salt addition. The experiment was carried out under greenhouse conditions, where the midday photosynthetic photon flux density was approximately $1,200 \mu \mathrm{mol} \mathrm{m} \mathrm{m}^{-2} \mathrm{~s}^{-1}$, the mean air temperatures were $31.5 \pm 2{ }^{\circ} \mathrm{C}$ during the day and $27.4 \pm 2{ }^{\circ} \mathrm{C}$ at night, and a mean relative humidity was $65.6 \pm 10 \%$.

Chlorophyll fluorescence parameters were measured using a leaf chamber fluorometer (6400-40, LI-COR, USA) coupled to a portable photosynthesis system (LI-6400-XT, LI-COR, USA). The following parameters were measured: maximum quantum yield of PSII in dark-adapted leaves $[\mathrm{Fv} / \mathrm{Fm}=(\mathrm{Fm}-$ Fo $) / F m$ ], effective quantum yield of PSII [ФPSII $=\left(\mathrm{Fm}^{\prime}-\mathrm{Fs}\right) /$ Fm'], apparent electron transport rate [ETR $=($ DPSII $x$ PPFD $x$
$0.5 \times 0.84)]$, relative energy excess at the PSII level $[\mathrm{EXC}=(\mathrm{Fv} /$ $\mathrm{Fm})-(\Phi \mathrm{PSII}) /(\mathrm{Fv} / \mathrm{Fm})]$ and photochemical $\left[\mathrm{qP}=\left(\mathrm{Fm}^{\prime}-\mathrm{Fs}\right) /\right.$ $\left.\left(\mathrm{Fm}^{\prime}-\mathrm{Fo}{ }^{\prime}\right)\right]$ and non-photochemical $\left[\mathrm{NPQ}=\left(\mathrm{Fm}-\mathrm{Fm}^{\prime}\right) / \mathrm{Fm}^{\prime}\right]$ quenching. To calculate the ETR, 0.5 was used as fraction of the excitation energy distributed to PSII, whereas 0.84 was used as fraction of incoming light absorbed by the leaves. PPFD was $1,000 \mu \mathrm{mol} \mathrm{m}^{-2} \mathrm{~s}^{-1}$.

Photosynthetic pigments were extracted from fresh leaf material. Discs from leaves were kept in the dark for $48 \mathrm{~h}$ at room temperature in $\mathrm{CaCO}_{3}$ saturated in dimethyl sulfoxide (DMSO). Absorbance of extracts was measured with a UV/ visible spectrophotometer for chlorophyll a, b and total, and carotenoids at $\mathrm{A}_{480}, \mathrm{~A}_{649}$ and $\mathrm{A}_{665}$, and concentrations were calculated using equations outlined by Wellburn (1994). Anthocyanins were extracted by agitating gently leaf discs in the dark for $48 \mathrm{~h}$ at $4{ }^{\circ} \mathrm{C}$ in $3 \mathrm{M} \mathrm{HCl}: \mathrm{H}_{2} \mathrm{O}: \mathrm{MeOH}(1: 3: 16 \mathrm{v}: \mathrm{v}: \mathrm{v})$. Anthocyanin content in the methanolic extracts was estimated as $\mathrm{A}_{530}-0.24 \mathrm{~A}_{653}$, as described by M'rah et al. (2010).

Experimental design was completely randomized with a $5 \times 2$ factorial scheme, which was composed by five nitrogen sources (percentage of $\mathrm{NO}_{3}^{-}$in relation to $\mathrm{NH}_{4}^{+}$of 100:0, 75:25, 50:50, $25: 75$ and $0: 100)$ and two salinity levels ( 0 and $75 \mathrm{mM} \mathrm{NaCl})$. The analyses were performed using five repetitions per treatment. The data were submitted to analysis of variance (ANOVA) and the means were compared using Tukey's test $(\mathrm{p} \leq 0.05)$ by the Sisvar program (São Paulo, Brazil).

\section{Results AND Discussion}

In general, in control, contents of chlorophyll a and carotenoids were higher in plants supplied with $\mathrm{NO}_{3}^{-}(100: 0$ ratio) than in the ones grown with $\mathrm{NH}_{4}^{+}(0: 100$ ratio) (Table 1). Salinity reduced the contents of chlorophyll total and carotenoids only in plants from treatment 100:0. On the other hand, in plants grown with the same amounts of $\mathrm{NO}_{3}^{-}$and $\mathrm{NH}_{4}^{+}$(50:50 ratio), salt stress promoted a $32 \%$ increase in the chlorophyll b content. In presence of salinity, the highest values of chlorophyll b content were observed in plants from treatment 50:50 and the lowest in the ones grown in the ratios 100:0 and $75: 25$, respectively; whereas the opposite, at least in part, was observed for carotenoids contents (Table 1). Under control conditions, the highest values of anthocyanins were found in plants in the ratios 0:100 and 25:75. The anthocyanins content was reduced by salinity in plants under treatments 100:0, 25:75 and 0:100, whereas it increased in plants grown with ratio 50:50. Additionally, stressed plants under 50:50 treatment displayed the highest accumulation of anthocyanins in the leaves (Table 1).

Several studies have cited reductions in photosynthetic pigments by salinity (Sudhir \& Murthy, 2004; Miranda et al., 2013b). In this study, S. bicolor plants supplied by ratio 100:0 showed decreases in chlorophyll total and carotenoids (Table 1); conversely, nitrogen nutrition with ratio 50:50 was able to increase the chlorophyll $\mathrm{b}$ content under $\mathrm{NaCl}$ stress. The higher chlorophyll $\mathrm{b}$ content may be attributed to an enhanced oxidative protection displayed by anthocyanins (Table 1). Anthocyanins are known as potent antioxidants and their 
Table 1. Concentrations of chlorophyll (Chl), carotenoids and anthocyanins of Sorghum bicolor plants cultivated in five combinations of nitrogen nutrition, supplied as $\mathrm{NO}_{3}: \mathrm{NH}_{4}{ }^{+}$, in presence of $\mathrm{NaCl}$ at 0 (control) and $75 \mathrm{mM}$ (salt stress) ${ }^{\#}$

\begin{tabular}{|c|c|c|c|c|c|c|c|c|c|c|}
\hline \multirow{3}{*}{$\mathrm{NO}_{3}: \mathrm{NH}_{4}+$ ratio } & \multicolumn{2}{|c|}{ Chl a } & \multicolumn{2}{|c|}{ Chl b } & \multicolumn{2}{|c|}{ Chl total } & \multirow{2}{*}{\multicolumn{2}{|c|}{ Carotenoids }} & \multirow{2}{*}{\multicolumn{2}{|c|}{$\begin{array}{c}\text { Anthocyanins } \\
\mathrm{mmol} \mathrm{g}^{-1} \mathrm{FM}\end{array}$}} \\
\hline & \multicolumn{6}{|c|}{$\mathrm{mg} \mathrm{g}^{-1} \mathrm{DM}$} & & & & \\
\hline & Control & Stress & Control & Stress & Control & Stress & Control & Stress & Control & Stress \\
\hline $100: 0$ & $4,53^{\mathrm{Aa}}$ & $4,28 \mathrm{Aa}$ & $1,67^{\mathrm{Aa}}$ & $1,50^{\mathrm{Ac}}$ & 6,20 Aa & $5,79 \mathrm{Ba}$ & $0,89 \mathrm{Aa}$ & $0,82^{\mathrm{Ba}}$ & 1,66 Aab & $1,48^{\mathrm{Bb}}$ \\
\hline $75: 25$ & 4,03 Aab & $4,22 \mathrm{Aa}$ & $1,61^{\text {Aa }}$ & $1,50 \mathrm{Ac}$ & $5,64 \mathrm{Aa}$ & 5,71 Аа & 0,83 Aab & 0,83 Аа & $1,54 \mathrm{Abc}$ & $1,59 \mathrm{Aab}$ \\
\hline $50: 50$ & 3,97 Aab & $3,68 \mathrm{Aa}$ & $1,73^{\mathrm{Ba}}$ & $2,28 \mathrm{Aa}$ & $5,69 \mathrm{Aa}$ & 5,96 Аа & $0,74^{A b}$ & $0,70^{\mathrm{Ab}}$ & $1,47^{\mathrm{Bc}}$ & $1,69 \mathrm{Aa}$ \\
\hline $25: 75$ & $4,12^{\text {Aab }}$ & $4,26 \mathrm{Aa}$ & $2,01^{\mathrm{Aa}}$ & $2,00^{\mathrm{Aab}}$ & $6,14^{\mathrm{Aa}}$ & 6,26 Аа & $0,76^{\mathrm{Ab}}$ & $0,82^{\mathrm{Aa}}$ & 1,79 Аа & $1,48^{\mathrm{Bb}}$ \\
\hline $0: 100$ & 3,79 Аb & 3,78 Аа & $1,85 \mathrm{Aa}$ & $1,78^{\mathrm{Abc}}$ & $5,64 \mathrm{Aa}$ & 5,57 Аа & $0,79 \mathrm{Ab}$ & $0,78^{\text {Aab }}$ & 1,80 Аа & $1,30^{B C}$ \\
\hline
\end{tabular}

\#In the same nitrogen source, different capital letters denote significant differences due to salt stress and; in the same salinity level, different lowercase letters represent significant differences due to nitrogen nutrition according to Tukey's test $(p \leq 0.05)$. The data represent the mean $(n=5)$

accumulation possibly prevented photo-oxidative damage to leaf cells, reducing the harmful effects of salt stress in 50:50-grown sorghum plants (Been Saad et al., 2012).
Salinity did not promote photoinhibition of PSII photochemistry, as provided by $\mathrm{Fv} / \mathrm{Fm}$ ratio (Figure $1 \mathrm{~A}$ ); furthermore, plants grown with equal amounts of $\mathrm{NO}_{3}^{-}: \mathrm{NH}_{4}^{+}$

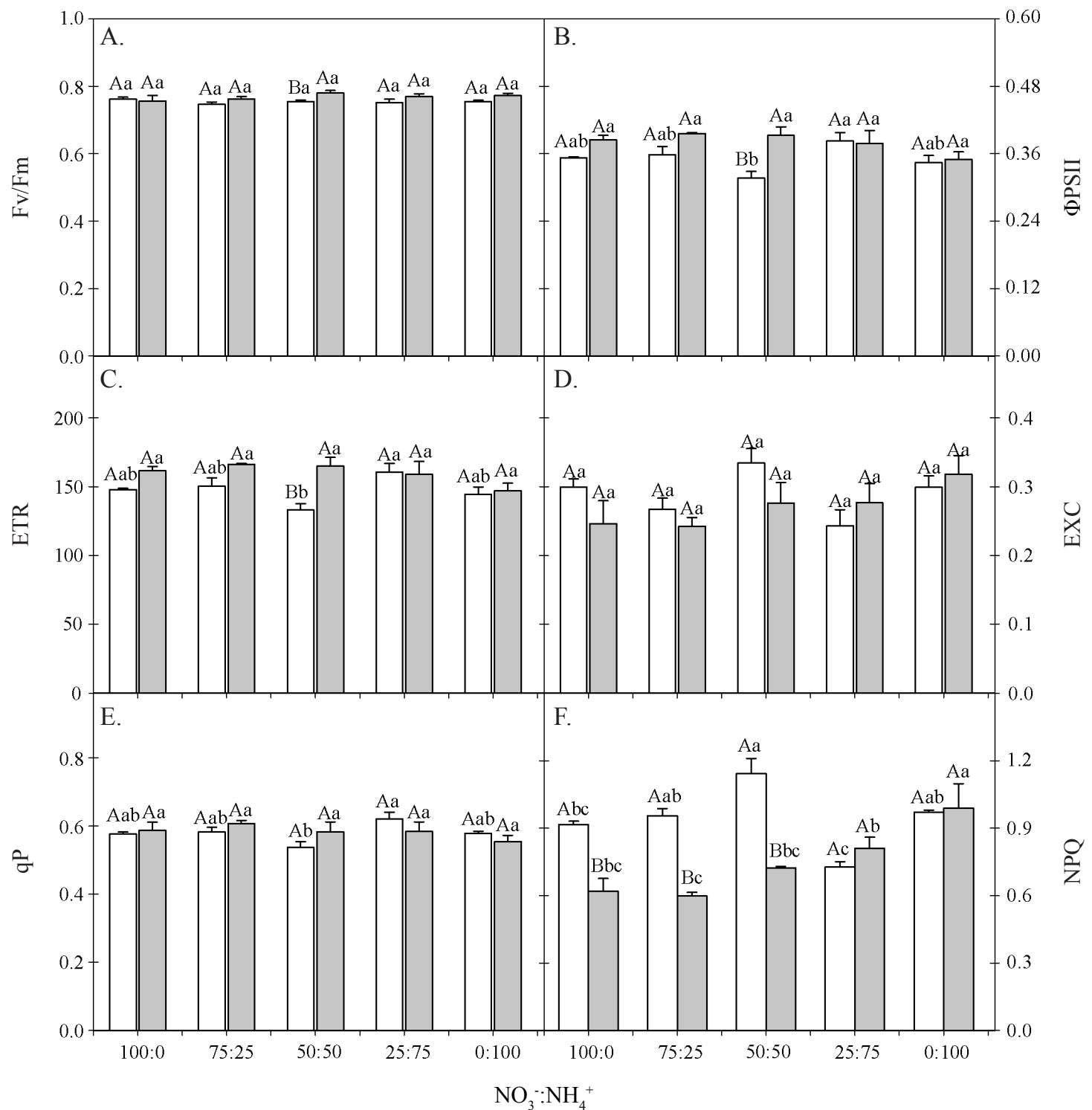

Measurements were performed ten days after salinity imposition. In the same nitrogen source, different capital letters represent significant differences due to salt stress and; in the same NaCl level, different lowercase letters represent significant differences due to the nitrogen source tested using Tukey's test $(p \leq 0.05)$

Figure 1. Photosystem II maximum efficiency - Fv/Fm (A), effective quantum yield of PSII - ФPSII (B), electron transport rate - ETR (C), energy excess at the PSII level - EXC (D) photochemical quenching - $\mathrm{qP}(\mathrm{E})$ and non-photochemical quenching - NPQ (F) of sorghum plants cultivated in five combinations of nitrogen nutrition supplied as $\mathrm{NO}_{3}{ }^{-} \mathrm{NH}_{4}{ }^{+}$, under control (white bar) and salt stress (grey bar) conditions with $\mathrm{NaCl}$ at 0 and $75 \mathrm{mM}$ 

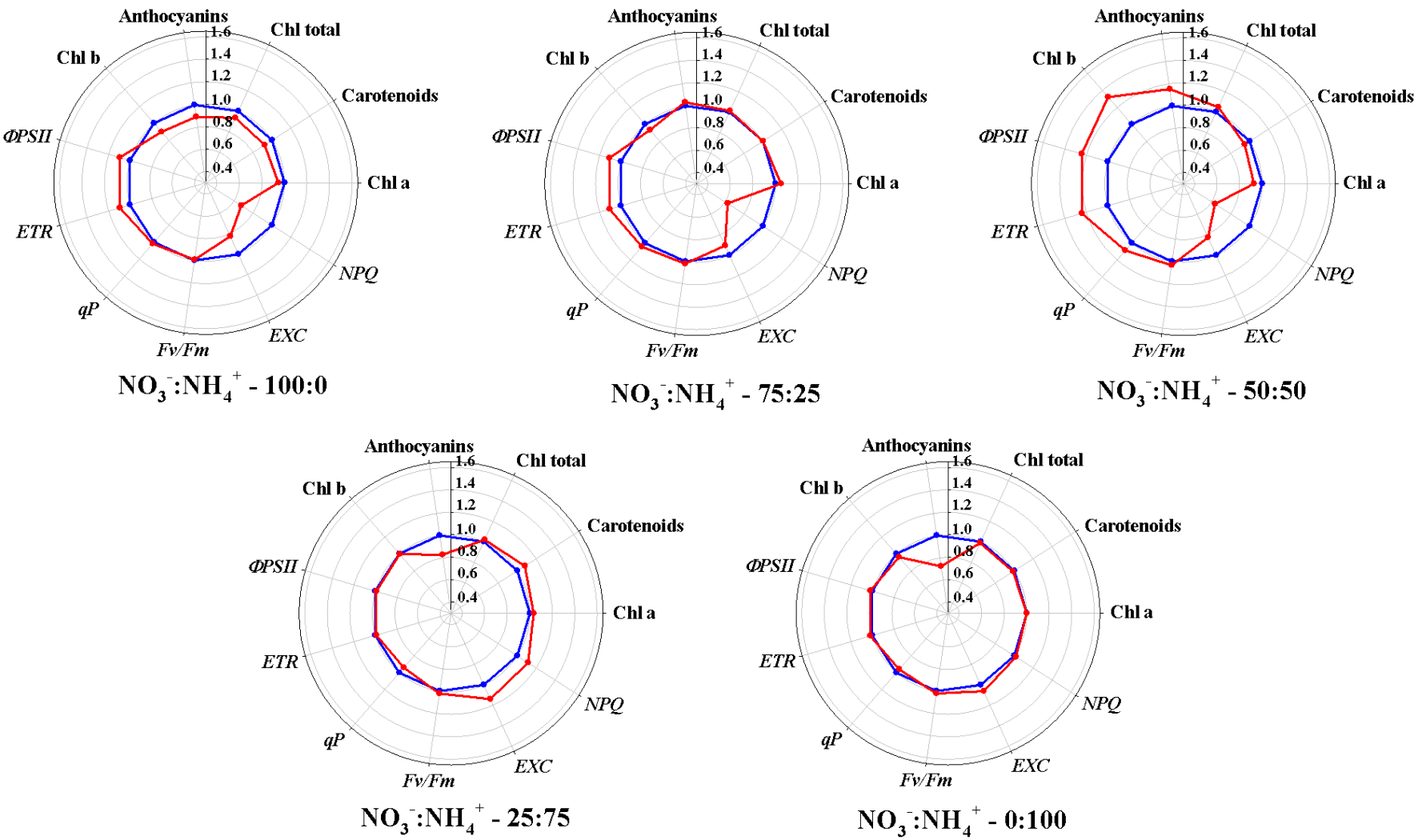

Contents of chlorophyll a ( $\mathrm{Chl} \mathrm{a}$ ), b (Chl b) and total (Chl total), carotenoids and anthocyanins; effective quantum yield of photosystem II ( $\Phi P S I I)$, electron transport rate (ETR), photochemical quenching (qP), photosystem II maximum efficiency (Fv/Fm), energy excess at the photosystem II level (EXC) and non-photochemical quenching (NPQ)

Figure 2. Overall representation of Sorghum bicolor physiological responses to salinity stress (red line). Nitrogen treatments supplied as $\mathrm{NO}_{3}^{-}: \mathrm{NH}_{4}{ }^{+}$ratios, in which the plants were grown, are individually presented in a radar plot. The reference plants were grown in absence of $\mathrm{NaCl}$ stress (blue line)

(50:50 ratio) displayed an increase in the PSII maximum efficiency $(\mathrm{Fv} / \mathrm{Fm})$ when subjected to salt stress. In absence of $\mathrm{NaCl}$, effective quantum yield of PSII (ФPSII) and electron transport rate (ETR) were higher and lower in plants grown in the ratios 25:75 and 50:50, respectively (Figure 1B and 1C). Under salinity conditions, plants cultivated in the ratio 50:50 strongly enhanced ФPSII and ETR compared to control. In general, energy excess at the PSII level (EXC) and photochemical quenching $(\mathrm{qP})$ were little or not altered by both $\mathrm{NO}_{3}^{-}: \mathrm{NH}_{4}^{+}$ratio and salinity stress (Figure $1 \mathrm{D}$ and $1 E)$. Non-photochemical quenching (NPQ) was higher in non-stressed plants treated with ratio 50:50 (Figure 1F). Salt stress severely decreased the NPQ of plants from treatments 100:0, 75:25 and 50:50. Additionally, under salinity conditions, $0: 100$-grown plants had higher NPQ values than the plants from other nitrogen treatments.

ФPSII estimates the efficiency at which light absorbed by PSII is used for quinone $A\left(Q_{A}\right)$ reduction (Baker, 2008). It provides an estimate of the quantum yield of linear electron flux through PSII. ETR estimates the noncyclic electron transport rate through PSII. Another component of PSII efficiency is the $\mathrm{qP}$, which results from using excitation energy within PSII to drive electron transport from $P 680$ to $Q_{A}$ (Baker, 2008). Herein, in control condition, it is plausible that 50:50-grown plants raised an excess of reducing power, as evidenced by the marked reduction in $\Phi$ PSII, ETR and $\mathrm{qP}$ (Figure $1 \mathrm{~B}$ and $1 \mathrm{C}$ ), and thus they displayed a large thermal dissipation, as denoted by the improved NPQ (Figure 1F).

$\mathrm{Fv} / \mathrm{Fm}$ ratio provides an estimate of the maximum efficiency of PSII photochemistry, which is the PSII operating if all the PSII centers are open $\left(\mathrm{Q}_{\mathrm{A}}\right.$ oxidized) (Baker, 2008). A decay in this ratio provides an indicator of photo-inhibitory damage induced by the incident photon flux density when plants are subjected to a wide range of environmental stresses (Bjorkman \& Demming, 1987; Aragão et al., 2012). In this study, as revealed by the high values of $\mathrm{Fv} / \mathrm{Fm}$, the significant photochemical alterations induced in the salt-stressed sorghum plants and cultivated with equal levels of $\mathrm{NO}_{3}{ }^{-}$and $\mathrm{NH}_{4}^{+}$were able to avoid the photoinhibition and photo-damage in PSII, thus allowing a favorable electron transport (ETR) and a higher ФPSII (Figure 1A, 1B and $1 \mathrm{C}$ ). As a result, these favorable processes might allow a higher electron-transport rate from PSII to $\mathrm{CO}_{2}$ assimilation under conditions of restrictions in the stomatal opening caused by salinity, as well as reduce the heat dissipation (NPQ). Additionally, the masking of chlorophyll by anthocyanins that prevent photo-oxidative damage is particularly important since it allows higher PSII efficiency (Been Saad, 2012).

Superior performance of 50:50-grown stressed plants may be associated with the greater accumulation of activated PSII reaction centers, as well as high capability for dissipation and transfer of the excitation energy. Nevertheless, it can be assigned to a mechanism to up-regulate photosynthetic electron 
transport so that production of ATP and NADPH would be in equilibrium with an improved photosynthetic capacity (Figure 1) (Lu \& Zhang, 2000). Moreover, up-regulating the linear electron transport among the two photosystems to match the demand of NADPH generation could decrease the electron transport to $\mathrm{O}_{2}$ on the acceptor side of PSII (i.e., in the Mehler reaction), thus minimizing the production of reactive oxygen species (Miller et al., 2010).

Radar plot evidences that the nitrogen nutrition in $S$. bicolor plants implies a differential pattern of responses to salt stress, demonstrating a key role of inorganic nitrogen source in ameliorating plant's sensibility to $\mathrm{NaCl}$ (Figure 2).

\section{Conclusions}

1. Inorganic nitrogen source directly affects the photosynthetic pigments of Sorghum bicolor plants under salinity.

2. Nitrogen supply with same amounts of nitrate and ammonium avoids the degradation of photosynthetic pigments and allows high PSII efficiency in salt-stressed Sorghum bicolor plants.

\section{ACKNOWLedgments}

The authors are grateful for the financial support provided by the Conselho Nacional de Desenvolvimento Científico e Tecnológico (CNPq) and Instituto Nacional de Ciência e Tecnologia em Salinidade (INCTsal).

\section{Literature Cited}

Aragão, R. M.; Silva, E. N.; Vieira, C. F.; Silveira, J. A. G. High supply of $\mathrm{NO}_{3}^{-}$mitigates salinity effects through an enhancement in the efficiency of photosystem II and CO2 assimilation in Jatropha curcas plants. Acta Physiologiae Plantarum, v.34, p.2135-2143, 2012.

Baker, N. R. Chlorophyll fluorescence: A probe of photosynthesis in vivo. Annual Review of Plant Biology, v.59, p.89-113, 2008.

Ben Saad, R.; Fabre, D.; Mieulet, D.; Meynard, D.; Dingkuhn, M.; Al-Doss, A.; Hassairi, A. Expression of the Aeluropus littoralis AlSAP gene in rice confers broad tolerance to abiotic stresses through maintenance of photosynthesis. Plant, Cell and Environment, v.35, p.626-643, 2012.

Bjorkman, O.; Demming, B. Photon yield of oxygen evolution and chlorophyll fluorescence characteristics at $77^{\circ} \mathrm{K}$ among vascular plants of diverse origin. Planta, v.170, p.489-504, 1987.

Britto, D. T.; Kronzucker, H. J. $\mathrm{NH}_{4}^{+}$toxicity in higher plants: A critical review. Journal of Plant Physiology, v.159, p.567584, 2002.

Fernández-Crespo, E.; Camañes, G.; García-Agustín, P. Ammonium enhances resistance to salinity stress in citrus plants. Journal of Plant Physiology, v.169, p.1183-1191, 2012.
Havaux, M. Stress tolerance of photosystem II in vivo: Antagonistic effects of water, heat, and photoinhibition stresses. Plant Physiology, v.100, p.424-432, 1992.

Kant, S.; Kant, P.; Lips, H.; Barak, S. Partial substitution of $\mathrm{NO}_{3}$ by $\mathrm{NH}_{4}{ }^{+}$fertilization increases ammonium assimilating enzyme activities and reduces the deleterious effects of salinity on the growth of barley. Journal of Plant Physiology, v.164, p.303-311, 2007.

$\mathrm{Lu}, \mathrm{C}$; Z Zhang, J. Photosynthetic $\mathrm{CO}_{2}$ assimilation, chlorophyll fluorescence and photoinhibition as affected by nitrogen deficiency in maize plants. Plant Science, v.151, p.135-143, 2000.

M'rah, S.; Nebli, H.; Kaddour, R.; Mahmoudi, H.; Lachaâl, M.; Ouerghi, Z. Influence of nitrate-ammonium ratio on growth and nutrition of Arabidopsis thaliana. Plant and Soil, v.336, p.65-74, 2010.

Miller, G.; Suzuki, N.; Ciftci-Yilmaz, S.; Mittler, R. Reactive oxygen species homeostasis and signalling during drought and salinity stresses. Plant, Cell and Environment, v.33, p.453-467, 2010.

Miranda, R. S.; Alvarez-Pizarro, J. C.; Araújo, C. M. S.; Prisco, J. T.; Gomes-Filho, E. Influence of inorganic nitrogen sources on $\mathrm{K}^{+} / \mathrm{Na}^{+}$homeostasis and salt tolerance in sorghum plants. Acta Physiologiae Plantarum, v.35, p.841-852, 2013a.

Miranda, R. S.; Ruppenthal, V.; Lopes, L. S.; Vieira, C. F.; Marques, V. B.; Bezerra, M. A.; Lacerda, C. F. Phosphorus fertilization improves soybean growth under salt stress. International Journal of Plant and Animal Science, v.01, p.21-29, 2013b.

Osmond, C. B.; Forster, B. Photoinhibition: Then and now. In: Demmig-Adams, B.; Adams, W.; Mattoo, A. (ed) Photoprotection, photoinhibition, gene regulation, and environment. Netherlands: Springer, 2006. p.11-22.

Saleem, A.; Ashraf, M.; Akram, N. A. Salt ( $\mathrm{NaCl})$ - induced modulation in some key physio-biochemical attributes in okra (Abelmoschus esculentus L.). Journal of Agronomy and Crop Science, v.97, p.202-213, 2011.

Sudhir, P.; Murthy, S. D. S. Effects of salt stress on basic processes of photosynthesis. Photosynthesis, v.42, p.481486, 2004.

Szepesi, A.; Csiszar, J.; Bajkan, S.; Gemes, K.; Horvath, F.; Erdei, L.; Deer, A. K.; Simon, M. L.; Tari, I. Role of salicylic acid pre-treatment on the acclimation of tomato plants to salt- and osmotic stress. Acta Biologica Szegediensis, v.49, p.123-125, 2005.

Wellburn, A. R. The spectral determination of chlorophylls $a$ and $b$, as well as total carotenoids, using various solvents with spectrophotometers of different resolution. Journal of Plant Physiology, v.144, p.307-314, 1994.

Zhonghua, T.; Yanju, L.; Xiaorui, G.; Yuangang, Z. The combined effects of salinity and nitrogen forms on Catharanthus roseus: The role of internal ammonium and free amino acids during salt stress. Journal of Plant Nutrition and Soil Science, v.174, p.135-144, 2011. 